\title{
Supply chain management in view of climate change: An overview of possible impacts and the road ahead
}

\author{
Thomas K. Dasaklis, Costas P. Pappis \\ University of Piraeus (Greece) \\ dasaklis@unipi.gr,pappis@unipi.gr
}

Received: June 2013

Accepted: September 2013

\section{Abstrac:}

Purpose The paper aims to provide a general overview of the impacts of climate change upon supply chains and to analyze the implications of climate change for supply chain management in terms of strategic and operational planning. A roadmap of fruitful research approaches is also presented.

Design/methoddogy/approadr The paper makes use of a general review of the relevant literature and, based on a systematic categorization of the findings, looks for useful insights towards the issues of climate change and supply chain management. A framework is drawn for systematically assessing the impacts of climate change upon supply chains and their management, while making suggestions for future research.

Findings: Supply chain networks run physical, operational and reputational risks attributed to climate change. Escalation in regulations, market forces and stakeholders' pressures are paving the way for the decarbonization of supply chains with obvious implications for supply chain management. Supply chain managers should pay special attention to the impacts of climate change on supply chains and academics should further explore the interrelationships between climate change and supply chain design and operations.

Research limitations/implications: Additional qualitative research based on grounded theory is suggested for validating and interconnecting the findings with empirical data. 
Practical implications: The paper provides several insights towards the issues of supply chain management in view of climate change and may serve as an initial basis for exploring future research directions by academics. Practitioners, especially those drafting value-creating supply chain agendas, may also find these insights useful for improving their managerial practices.

Originality/value By providing an original structured overview of the impacts of climate change upon supply chain design and operations management the paper substantiates the need for management improvements and provides research directions that may prove valuable to researchers.

Keywords: climate change, impacts of climate change, supply chain design and operations management

\section{Introduction}

Climate Change has emerged in recent years as one of the most critical topics at almost all levels of decision making, both private and public. This constitutes a radical change compared to the common perception only a few years ago. Climate Change, a result of global warming, is a reality of universal acceptance, affecting in many ways the life of human societies, business operations and the environment itself (Stern Review, 2006). In fact, businesses have to perform their climate change-prone operations in a more vigorous and risky environment where institutional, resource-based, supply chain and stakeholder views are all important to characterize and understand corporate strategic responses to a sustainability issue (Kolk \& Pinkse, 2007).

According to (Sussman \& Freed, 2008) there are three types of climate change risks that can affect business: risks to core operations, risks to the value chain and, finally, risks that arise from broader changes in the economy and infrastructure. Moreover, climate change mitigation and adaptation policies may further affect business operations in a rather indirect way. Businesses should think of climate change as a market issue as regulations towards climate change affect, among others, energy prices and availability, thus, creating a ripple effect throughout their entire value chain (Hoffman \& Woody, 2008). In particular, market issues and relevant market strategies should be taken into consideration when companies draft climate change policies (Hoffman \& Woody, 2008; Kolk \& Pinkse, 2005).

Climate change drivers like environmental treaties, shareholders' value and customers' changing buying patterns are posing threats and opportunities for businesses and their supply chain networks (Figure 1). During the last few years leading companies from diverse sectors have realized the threats and opportunities imposed by climate change and they are taking action steps towards implementing more robust climate change agendas. Even further, as 
more than three quarters of the Greenhouse gases (GHG) emissions associated with many industry sectors come from their supply chains, many leading companies are engaging their suppliers about managing GHG emissions in an effort to drive down emissions beyond their own operations (EPA Climate Leaders, 2010). Suppliers' selection methods are starting to incorporate climate change considerations and the engagement of suppliers for implementing carbon management strategies for the reduction of their GHG emissions in their supply chains is becoming almost mandatory (Carbon Disclosure Project, 2011b). It is estimated that logistics activities will grow by $23 \%$ between 2002 and 2020, representing 18\% of the European GHG emissions in 2020 (The Climate Group, 2008). Therefore, decarbonizing of supply chain networks is of great importance towards climate change mitigation efforts.

Although some authors have investigated issues of supply chain management (SCM) in view of climate change (Dekker, Bloemhof, \& Mallidis, 2012; Halldórsson \& Kovács, 2010; Hitchcock, 2012), the literature still remains fragmented along narrow research areas and several interdependencies between climate change and SCM are not well documented. Moreover, SCM in view of climate change has been so far seen through the lens of operations management perspective whereas issues of streamlining complexity across the supply chain have been poorly studied. As a consequence, from a strategic point of view, it is not clear from the literature how supply chain networks could be better positioned to capitalize upon changing climate conditions. This paper provides an overview of the impacts of climate change upon SCM and it further identifies the implications of climate change for SCM in terms of supply chain strategic and operational planning. Finally, the paper has been also intended to inspire future SCM research and challenge academics and researchers to further explore the interrelationships between climate change and SCM.

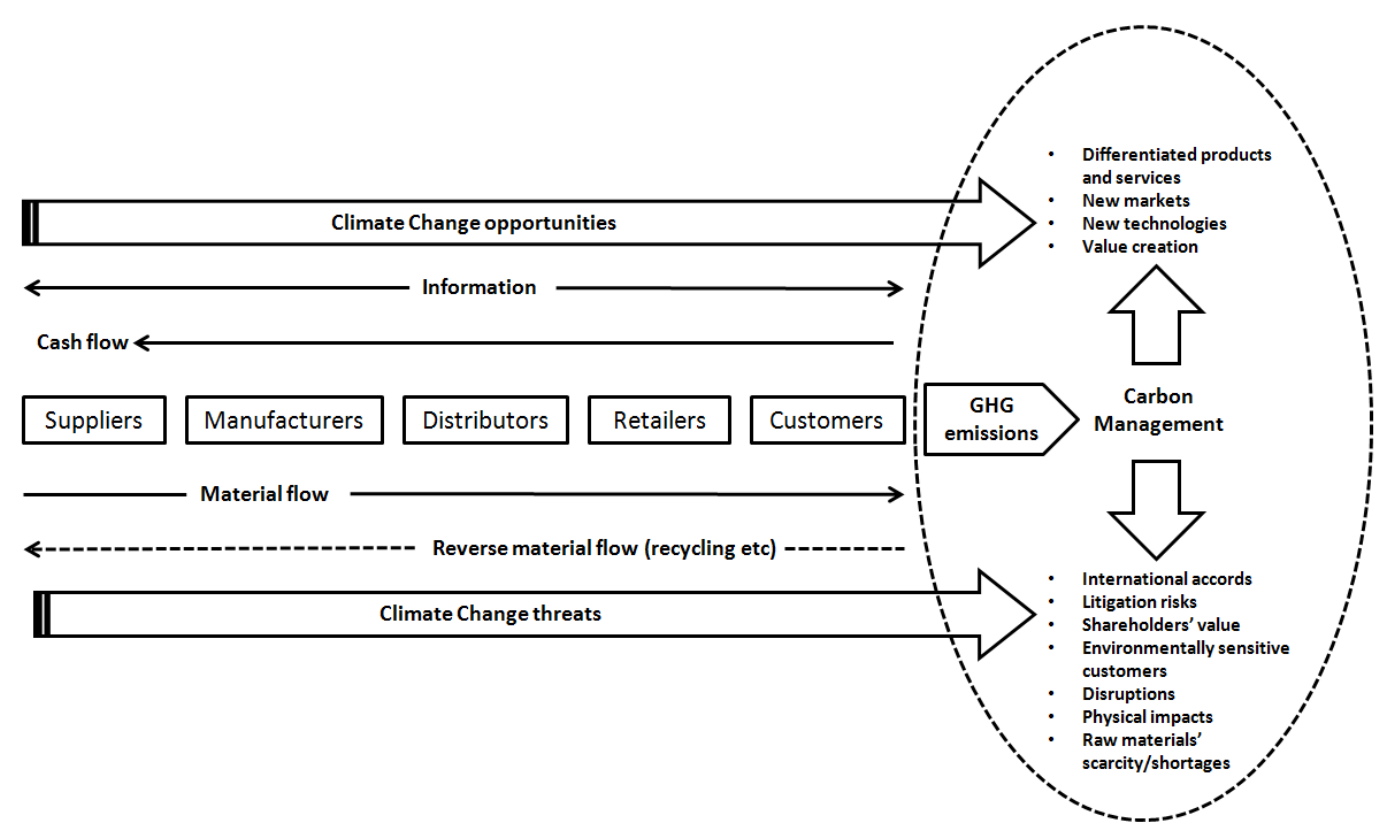

Figure 1. Climate Change threats and opportunities for supply chain networks 
The rest of the paper is structured as follows: Section 2 surveys the bibliography related to climate change and SCM. Section 3 deals with the development of an inventory of the stresses of climate change upon supply chain operations (manufacturing, transportation, warehousing and storage, wholesale and retail trade and, finally, consumption) in terms of direct (physical) and indirect (regulatory, market or reputational) risks. Section 4 outlines several implications of Climate Change for SCM. A roadmap of future research approaches is presented in Section 5. The paper ends with some concluding remarks.

\section{Literature review}

The literature of climate change and SCM may be classified into two main streams of studies. The first stream of studies are mostly theoretical and cope with the carbon management across the supply chain mostly in terms of minimizing total costs by taking into account carbon emissions parameters or carbon emission trading mechanisms. Carbon considerations are incorporated into supply chain modeling for decisions like network design, product mix, selection of modes of transportation, inventory control, suppliers' selection etc. Some studies also examine issues of energy efficiency in the logistics sector. The studies of the second category are more practical and they are closely related to "climate sensitive business" like agricultural, food or energy intensive (e.g. the automotive industry) sectors and they either provide assessments of climate change vulnerabilities or build on carbon footprints inventories for these specific sectors.

For example, the current and future implications of climate change with respect to energy efficiency for logistics and SCM have been investigated (Halldórsson \& Kovács, 2010). Carbon constraints are being integrated into modeling development for various supply chain decisions like network design (Chaabane, Ramudhin, Kharoune, \& Paquet, 2011; Chaabane, Ramudhin, \& Paquet, 2010; Elhedhli \& Merrick, 2012; Ramudhin, Chaabane, \& Paquet, 2010), transportation planning (Sadegheih, Drake, Li, \& Sribenjachot, 2011), the selection of different modes of transportation (Hoen, Tan, Fransoo, \& van Houtum, 2012) and inventory control (Hua, Cheng, \& Wang, 2011). Optimal product mix and production quantities in the presence of several different types of environmental constraints including emissions (Letmathe \& Balakrishnan, 2005) or issues of carbon labeling of products (McKinnon, 2010) have also been studied. Carbon aspects are also being incorporated into supply chain decisions like procurement and suppliers' selection (Hsu, Kuo, Chen, \& Hu, 2011; Shaw, Shankar, Yadav, \& Thakur, 2012). In addition, aspects of suppliers' engagement towards disclosing climate change information have also been studied (Jira \& Toffel, 2011). More holistic approaches examine the carbon footprint across supply chains (Sundarakani, De Souza, Goh, Wagner, \& Manikandan, 2010) or incorporate carbon parameters in operational decision-making with regard to procurement, production, and inventory management (Benjaafar, Li, \& Daskin, 2013). Other studies examine the environmental impacts of both online and conventional retail supply chains and they further examine the methodological issues associated with carbon 
auditing of these retail channels (Edwards, McKinnon, \& Cullinane, 2011). Finally, some tradeoff frameworks have also been developed between carbon emissions and logistics aspects like costs or performance (Abdallah, Farhat, Diabat, \& Kennedy, 2011; Alves Jr, MacIel, Lim, Magnani, \& Arcoverde Jr, 2011; Harris, Naim, Palmer, Potter, \& Mumford, 2011; Jaegler \& Burlat, 2012; Kim, Janic, \& Van Wee, 2009; Winebrake, Corbett, Falzarano, Hawker, Korfmacher, Ketha et al., 2008).

The second stream of studies copes with the psychical impacts (temperature variations, extreme weather patterns etc) of climate change upon crops and food production or with the development of carbon footprint inventories for specific sectors. As climate change is extremely context-specific, same sectors may be influenced differently according to their latitude (Jones, White, Cooper, \& Storchmann, 2005). Climate sensitive business like agriculture or food production and supply may be affected at a large scale (Haverkort \& Verhagen, 2008). More specifically, assessments of the impact of climate change have been carried out for a plethora of cases like timber (Peltola, Ikonen, Gregow, Strandman, Kilpeläinen, Venäläinen et al., 2010), coffee (Gay, Estrada, Conde, Eakin, \& Villers, 2006; Laderach, Lundy, Jarvis, Ramirez, Portilla, Schepp et al. 2011) and rice production (Hasan, 2010). Integrated approaches assessing the carbon footprint of specific sectors have also been carried out. For example, the life-cycle assessment methodology has been applied in order to determine the carbon footprint of different players involved in a supply chain of the textile sector (Bevilacqua, Ciarapica, Giacchetta, \& Marchetti, 2011). Issues of carbon footprint within the context of automobile supply chain have been examined (Lee, 2011, 2012) whereas an attempt has been made to project the carbon intensity of road freight transportation up to 2020 (Piecyk \& McKinnon, 2010). The approaches of the waste management sector to measure, report and verify its carbon footprint have been explored (Turner, Kemp, \& Williams, 2011). A comparative assessment of competing supply chains in the case of three European countries in terms of carbon emissions and energy consumption has been presented (Rizet, Browne, Cornelis, \& Leonardi, 2012). Finally, other studies cope with the complexity of the climate change and globalization challenge of the fresh produce supply chain where issues of microbiological food safety are examined (Jacxsens, Luning, van der Vorst, Devlieghere, Leemans \& Uyttendaele, 2010; Tirado, Clarke, Jaykus, McQuatters-Gollop, \& Frank, 2010).

\section{Impacts of Climate Change upon Supply Chain Operations}

Each link in a supply chain, while adding value to the product as it moves through it, contributes to environmental degradation, particularly climate degradation, through GHG releases. In turn, each link of the supply chain is subjected to risks and opportunities due to climate change in the form of extreme events and other phenomena such as flooding or high winds, higher frequency of hot summers, desertification, sea level rise, hurricanes, temperature changes, changes in local weather patterns, increase in storm intensity and frequency, water shortages, spread of diseases etc. Therefore, climate change and supply 
chain operations are mutually affected. Examples of possible climate change impacts to different links in the supply chain are summarized in Table 1.

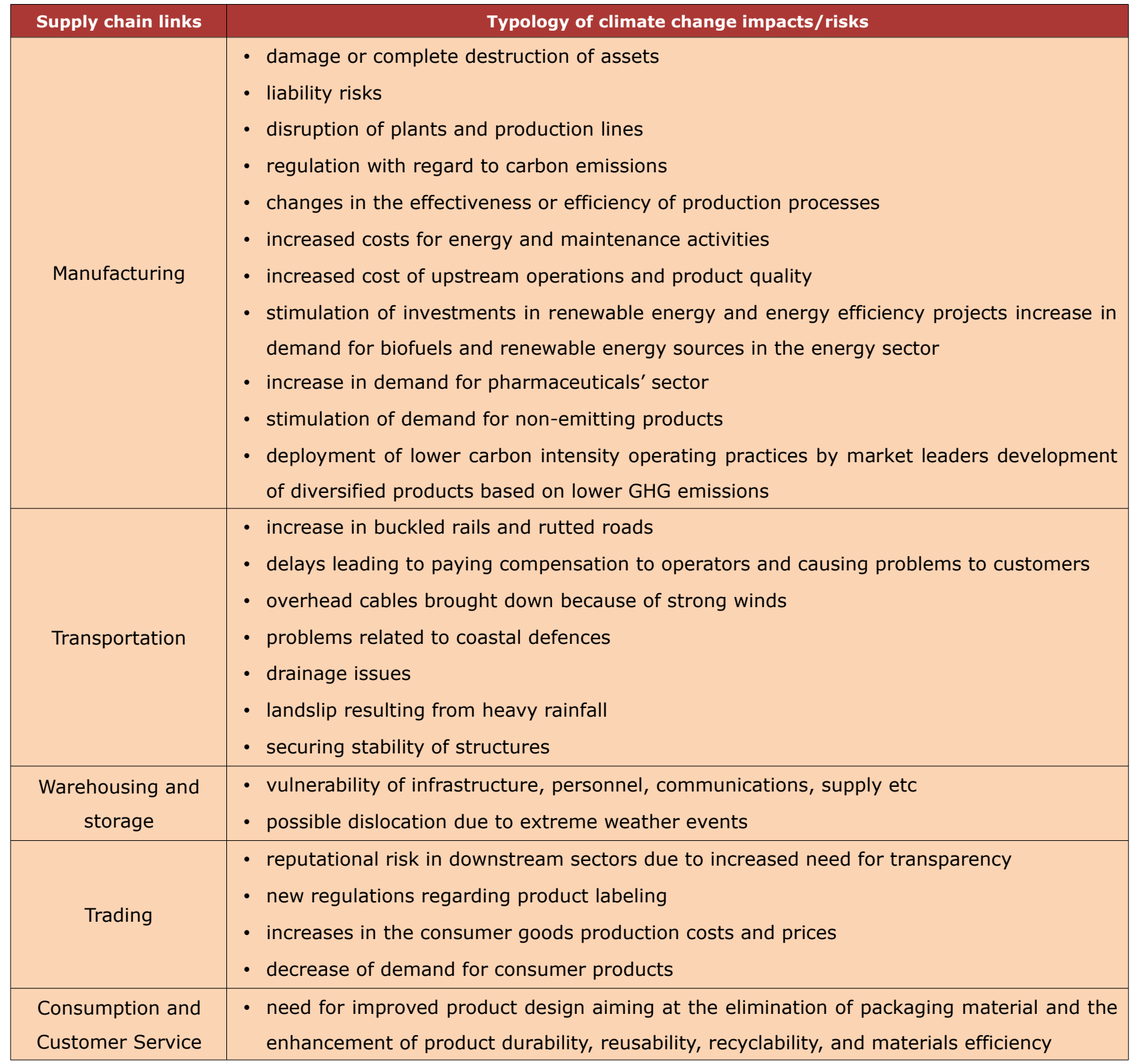

Table 1. Climate change impacts to supply chain links

\subsection{Manufacturing}

The CDP report for 2011 (Carbon Disclosure Project, 2011a) provides valuable information about climate change impacts to different sectors and sub-sectors. Different sectors are affected in many ways by climate change, some of which are common, like extreme weather events. Manufacturing processes are subject to a wide range of regulation with regard to carbon emissions and there is likely to be more to come. For example, the automotive industry needs to keep abreast of changes in the regulatory landscape in areas such as fuel efficiency standards, environmental taxes and biofuels targets. The Energy sector is faced with risks due to the uncertainty of future changes in post-Kyoto regulation, including increased costs attributed to the introduction of carbon taxes. In the Pharmaceuticals sector, inputs to 
production may be affected due to the loss of biodiversity or water scarcity which will eventually cause disruption of manufacturing processes. Extreme weather conditions could affect many operations of the Utility sector (e.g. transmission cables impacted by higher temperatures and greater electricity use during extreme heat). The proximity of energy generating plants may be subject to disruptions as their proximity to water renders them vulnerable to storm surges and rises in sea level. The Materials' sector is vulnerable to precipitation patterns and water availability. Shortages of water could increase operational costs and could lead to increased competition for water between local communities and the operations sites. More heavy rains over shorter periods could cause flooding in transport infrastructures, disrupting roads so the delivery of products is compromised. Changing fuel regulations and carbon taxes may lead to financial penalties and loss of demand for products of the Consumer Discretionary's sector. Additionally, sourcing materials may become more difficult resulting in price rises and resource constraints. The Industrials sector is vulnerable to physical risks, such as extreme weather events and rising sea levels, because the latter could cause production factories to shut down. It is obvious that all the aforementioned sectors run regulatory risks and potential reputational losses.

As far as opportunities in manufacturing are concerned, international market-based trading mechanisms may stimulate the investments in renewable energy and energy efficiency projects or the demand for biofuels and renewable energy sources in the energy sector. The Pharmaceuticals' sector may see an increase in demand for its products as there will be a need for greater disease prevention and more patient treatments. Air pollution regulations and carbon emissions reduction targets could stimulate the demand for non-emitting (at point of use) products such as electric vehicles in the Utilities' sector. Market leaders of the Materials' sector may take advantage of rigid regulating emission schemes in order to deploy lower carbon intensity operating practices compared to their rivals and, of course, to gain bigger market shares. The Consumer Discretionarys' sector could take advantage of developing diversified products based on lower GHG emissions in an effort to meet consumption trends and comply with regulations. Also, investment in research for greener technologies in the Automobile sector (e.g. electric cars, hybrid cars) will be stimulated. As a result of regulatory requirements, the Industrials sector will experience new commercial opportunities for products and services (e.g. products that track GHG emissions and energy consumption, and products with suitable durability to extreme increases/decreases in temperature). Companies of the Industrials sector are currently seeing opportunities to lobby and influence regulations and international accords, moving customers towards their own products and services.

\subsection{Transportation}

Transportation, like production, is one of the major contributors to the global warming effect and, certainly, an important factor for energy efficiency in the supply chain (Halldórsson \& Kovács, 2010). It is through movement, at least in most modes of material transportation, 
fuels, particularly fossil fuels, get directly used and pollutants, including GHG, are released into the atmosphere. In other modes of transportation (e.g. liquids transported by means of pipelines) fuels are indirectly used, in direct (first-tier) and all other suppliers further up the supply chain (e.g. for pipeline construction). Some studies reveal the potential improvement in terms of reducing GHG emissions in transportation, especially $\mathrm{CO} 2$ emissions, when the consolidation of freight between supply chains, namely pooling supply networks or supply chains, is applied (Pan, Ballot, \& Fontane, 2010).

The effects of climate change on transport operations due to global warming are serious and may become severe. Indeed, extreme weather events may have very costly and even catastrophic implications in all kinds of material's movement. For example, extreme weather events may trigger adjustments to speed factors and therefore influencing travel speeds (Maoh, Kanaroglou \& Woudsma, 2008). As pointed out in (Sussman \& Freed, 2008), a general increase in temperature and a higher frequency of hot summers are likely to result in an increase in buckled rails and rutted roads, which involve substantial disruption and repair costs. A comprehensive list of climate change impacts on transport and corresponding actions required in order to cope with them can be found in (Humphrey, 2008).

\subsection{Warehousing and storage}

Warehousing and storage are activities that typically appear in all supply chains, closely connected with distribution. They have their share in the global warming effect, either as direct or indirect contributors. Large quantities of product sitting idle in a warehouse might seem minimally polluting, but warehouses often take up valuable land and consume resources, even in a static state (White, 2007). They are large building footprints absorbing and reflecting heat, and facilities that consume large amounts of energy to operate and control climate. Also, warehouses can be sources of other pollutants because they often handle hazardous materials, and there is a trade-off between the marginal release of pollutants and the output handling of hazardous materials. Improving throughput, reducing the amount of idle inventory taking up space and more efficient use of space can have a significant impact on environmental issues associated with storage, although idle inventory and resources may actually be greener.

\subsection{Wholesale and retail trade}

Regarding wholesale and retail trade, they both use infrastructure, equipment and processes, which are vulnerable to climate change risks. Trade is synonymous to supply, which, implies use of inventory facilities (buildings, material handling equipment etc), material movement and transport facilities and infrastructure (e.g. ports, highways, trucks, trains etc), personnel, communications, etc. All these may be hit by extreme weather events due to climate change. According to the (Carbon Disclosure Project, 2011a), the Food Retailing sector runs reputational risk as its visibility in the market and the increasing transparency of its operations, combined with NGO power, drives companies to source more sustainable materials. 
In addition, new regulations for product labeling could increase the costs associated with producing consumer goods. In order these increases be absorbed, the retail sector would have to increase the price of the products, causing reduction to demand for these products.

\subsection{Consumption and Customer Service}

The output of the supply chain finally reaches the consumer. The product is consumed, and everything around the consumption is wasted (White, 2007), with obvious impacts generally in the environment and, specifically, in global warming. Automotive industry is a very typical example of the severity of a sector's products in terms of GHG emissions during the utilization phase. It is estimated that while about $10 \%$ of the lifetime GHG emissions from a vehicle occur during its production phase the remaining $90 \%$ is emitted while customers are using it (Ford, 2005). According to several studies, products and packaging are associated with a large share of greenhouse gas emissions and this share is even bigger when products are imported and not produced inland (Product Policy Institute, 2009).

\subsection{The role of Technology}

One important parameter affecting the relation between climate change and supply chain operations is Technology in its three dimensions, materials, production methods and management. The implementation of new Information and Communications Technology strategies (ICT) in particular could assist in the decarbonization of many processes. In the case, for example, of freight transportation, ICT may increase capacity utilization and, therefore, lead to reductions in energy usage (Nash, Weidmann, \& Luethi, 2009). It can also enhance the reporting capabilities of big corporations willing to disclose information regarding the emissions of their entire value chain through the usage of sustainability software and enhance the visibility of GHG emissions across supply chains (Carbon Disclosure Project, 2011a).

Generally, ICT industry presents several opportunities for replacing goods and services with virtual equivalents. ICT industry also provides the means of technological innovation in order to enable energy efficiency and $\mathrm{CO} 2$ reductions across several sectors such as transport, buildings, power and industry. Dematerialization, smart motor systems, smart logistics, smart buildings and smart grids are the opportunities by which ICT could reduce emissions across the aforementioned sectors. For example, Smart logistics systems consist of a range of software and hardware tools that monitor, optimize and manage operations and they are utilized for the design of transportation networks, the efficient management of centralized distribution networks, intermodal load shifts, eco-driving etc. The adoption of such technologies reduces storage space for inventory, fuel consumption, total kilometers driven and the frequency of vehicles traveling empty or partially loaded. ICT can make a major contribution to the global response to climate change, reducing up to $15 \%$ the emissions of Business-As-Usual in 2020, yielding at the same time significant energy and fuel savings (The Climate Group, 2008). 


\section{Implications of Climate Change for supply chain management}

Climate change and its impacts force businesses to compete in an environment even more volatile than until recently. Customers are already seeking for high quality products and services at low prices which embed environmental concerns like carbon footprint and energy efficiency (Song \& Lee, 2010). Companies failing to incorporate this message into their own supply chain strategy or unwilling to address climate change issues will be eventually "punished" by environmentally-sensitive customers. Furthermore, given the fact that "supply chains compete, not companies" (Christopher, 1998) it is more than obvious that SCM will play a crucial role on meeting new customers' requirements in view of climate change and it is the appropriate supply chain strategy that will enable a firm to fully take advantages of the opportunities of climate change while minimizing threats. In the low carbon era we have entered, it seems that low carbon SCM will be the driver for enhancing competence (Yang \& Zhang, 2011). Regulatory, physical and market drivers stemming from climate change create threats and opportunities for supply chains. Consequently, several implications for supply chain strategic and operational management must be adequately addressed (Figure 2).

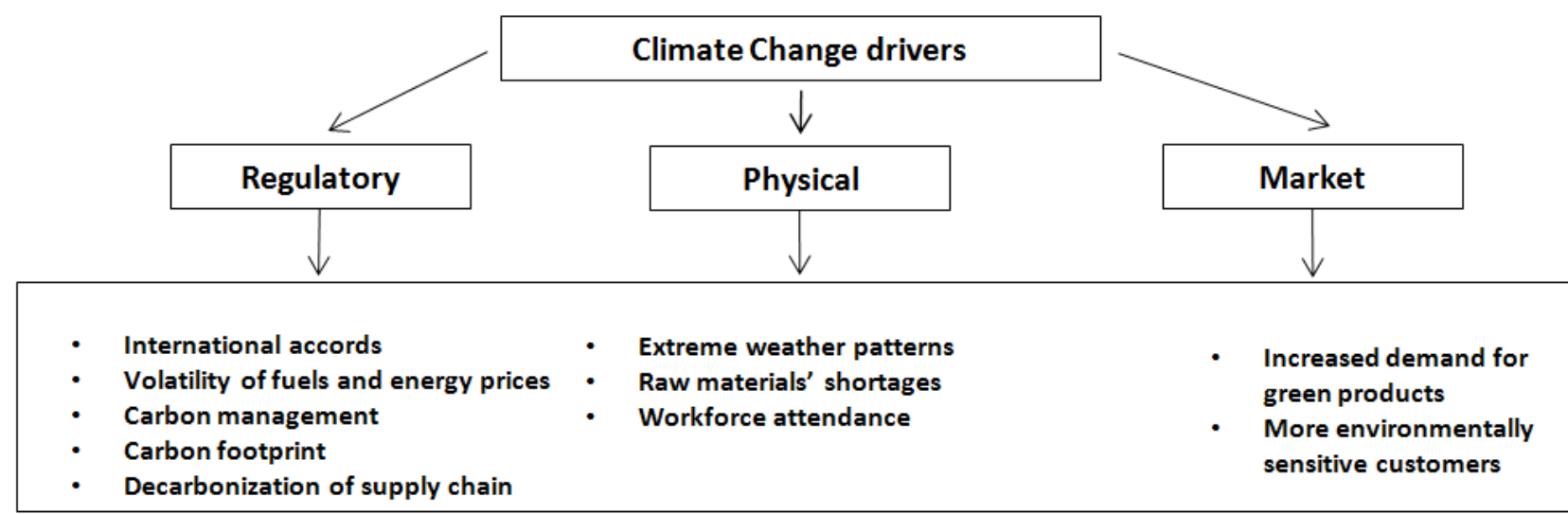

Implications for Supply Chain Management

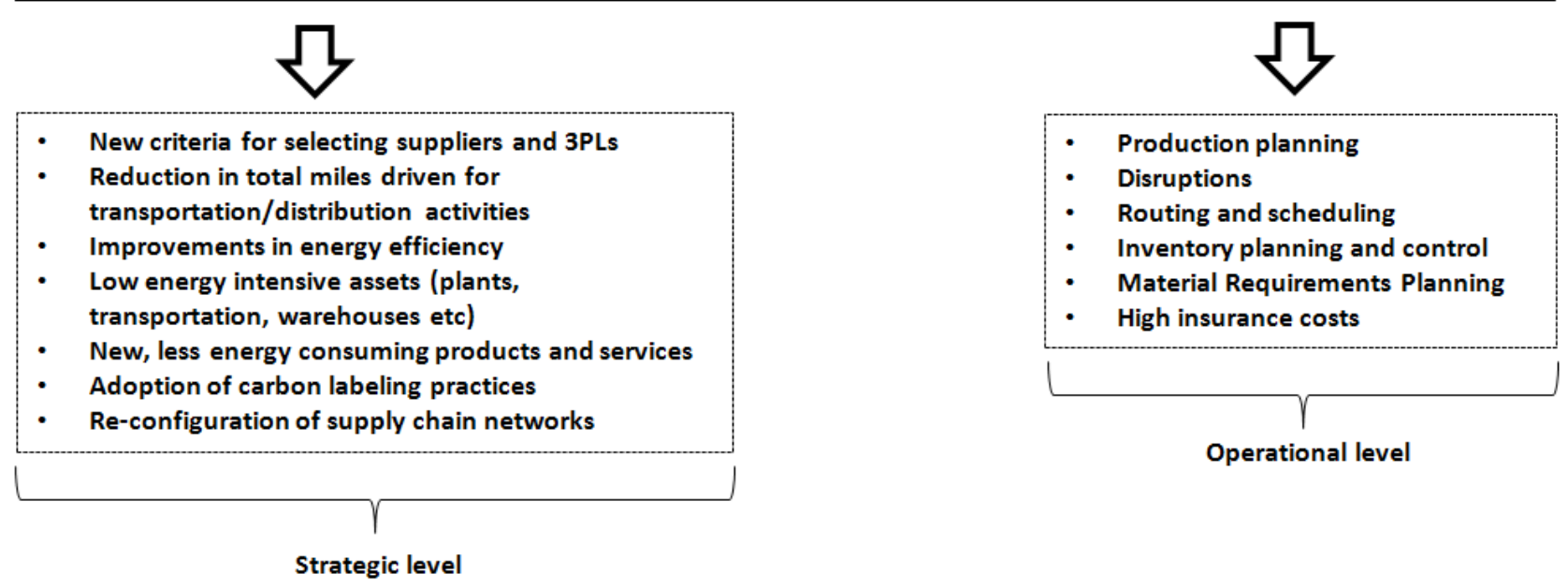

Figure 2. Implications of climate change drivers for SCM 


\subsection{Implications of Climate Change at the supply chain strategic level}

Climate change stresses add uncertainty to supply chain networks, especially for globalized ones operating across continents. According to (McKinnon, 2009), the centralization of inventory experienced during the past 40 years has increased the vulnerability of supply chains to extreme weather patterns like flooding. Therefore, climate change hazards should be taken into consideration during the design phase of supply chain networks in order to protect them from disruptions and vulnerabilities to both physical and regulatory risks. With respect to the strategic level, five clusters of implications could be identified: facility location, product design, transportation and distribution, sourcing and supply chain network configuration. Table 2 presents important climate change implications for the different aspects of supply chain design.

With respect to supply chain configuration, lean, agile and leagile paradigms have been proposed to be the most prevalent paradigms under which supply chains may be configured and operate (Ben Naylor, Naim, \& Berry, 1999; Christopher, 2000; Mason-Jones, Naylor, \& Towill, 2000). The answer to the question "which one of the three paradigms is more environmental friendly, and, furthermore, accounts for fewer emissions" is not straightforward. For example, there is no scientific consensus so far whether the lean paradigm is green (King \& Lenox, 2001; Rothenberg, Pil, \& Maxwell, 2001). It is also hard to define which paradigm is more vulnerable to climate change stresses. Each paradigm has its own characteristics and therefore different exposure levers to climate change hazards may apply. Therefore, in view of climate change, all three paradigms are subject to pressures as the configuration of their building blocks necessitates a pre-determined level of both synchronization and alignment, while aspects of coordination, collaboration and information sharing may also arise. Although the configuration of supply chains may not undergo changes at a great scale as a result of climate change, adjustments should be made which could reduce vulnerabilities while offering a competitive advantage. These adjustments stem from the different level of vulnerability their building blocks present to climate change hazards. Certain supply chain configurations, that will have the capacity of absorbing any negative effects attributed to climate change, could create a competitive advantage.

\begin{tabular}{|c|c|}
\hline $\begin{array}{l}\text { Aspects of } \\
\text { supply chain } \\
\text { design }\end{array}$ & Climate change implications \\
\hline Facilities & $\begin{array}{l}\text { - imposition of regulatory frameworks in certain geographical areas } \\
\text { - technologation of energy-intensive production processes } \\
\text { - capacity planning affected by specific production technologies adopted (producing fewer } \\
\text { emissions) } \\
\text { - placement of facilities as near as possible to consumption sites (minimization of transportation } \\
\text { costs and total emissions) } \\
\text { - proximity aspects (manufacturing plants producing "green" products directed towards more } \\
\text { "green-sensitive" markets) } \\
\text { - resources' scarcity (Reich-Weiser \& Dornfeld, 2009) }\end{array}$ \\
\hline
\end{tabular}




\section{Aspects of}

supply chain

design

\begin{tabular}{|c|c|}
\hline Sourcing & 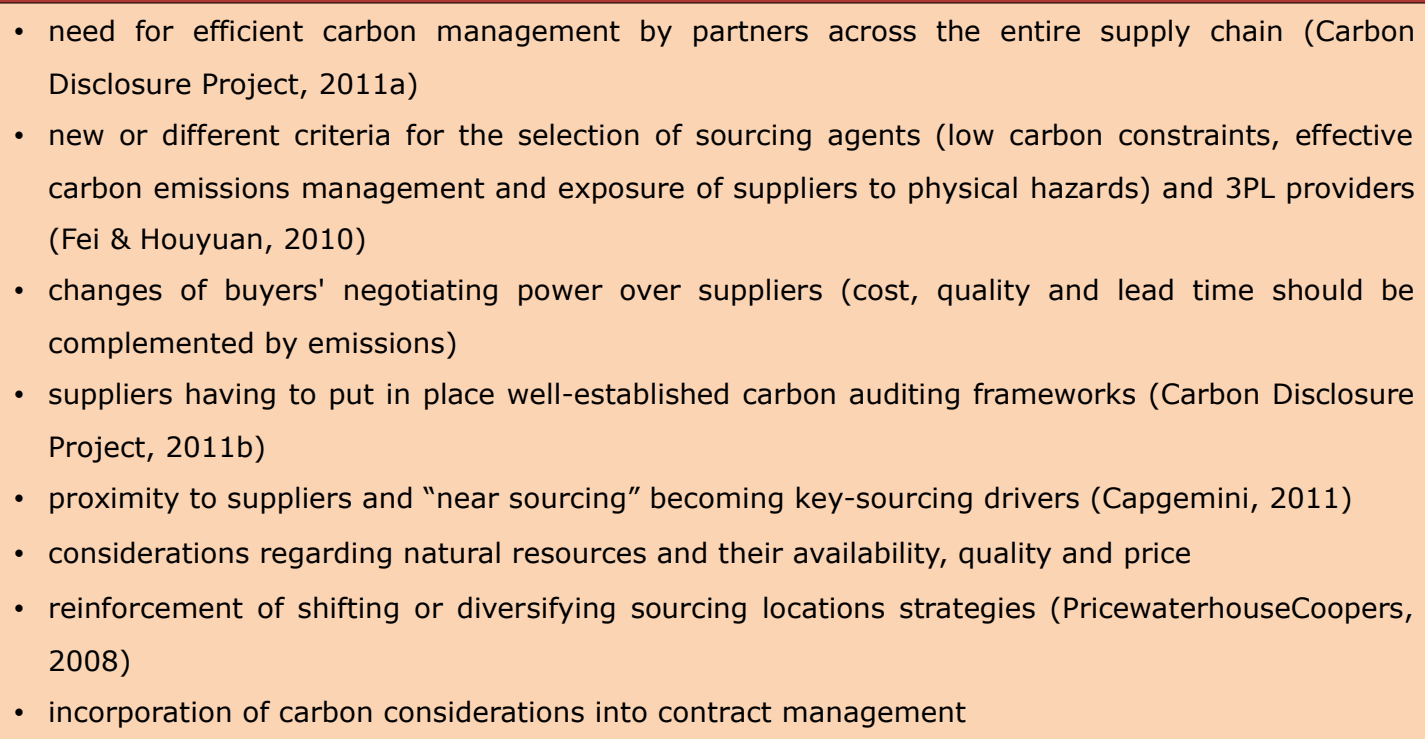 \\
\hline $\begin{array}{l}\text { Transportation } \\
\text { and } \\
\text { distribution }\end{array}$ & $\begin{array}{l}\text { - emissions reduction forcing total miles driven and number of nodes downwards } \\
\text { Commerce Initiative \& Capgemini, 2008) } \\
\text { - new drivers for selecting modes of transportation and distribution considering with vehicles' } \\
\text { technology, the utilization of low carbon fuels, the usage of lightweight materials, aerodynamics, } \\
\text { infrastructure quality (regarding rolling resistance), broader adoption of ICT solutions for route } \\
\text { optimization (The Climate Group, 2008) and capacity planning etc } \\
\text { - switches between the usage of energy and less energy intensive transportation modes } \\
\text { (Winebrake et al., 2008) } \\
\text { - new approaches of delivering products to customers (neighborhood delivery) or transporting } \\
\text { products (collaborative transportation management) (Global Commerce Initiative \& Capgemini, } \\
\text { 2008) } \\
\text { transportation assets placed in locations where vulnerability assessments have been carried out } \\
\text { (physical hazards) }\end{array}$ \\
\hline & $\begin{array}{l}\text { - evaluation of alternative scenarios for product design using GHG inventories involving alternative } \\
\text { materials, sources of purchasing, production processes, parameters affecting better handling and } \\
\text { storage of products and packaging options or more light weight materials) (EPA Climate Leaders, } \\
2010 ; \text {; World Resources Institute \& World Business Council for Sustainable Development, 2011) } \\
\text { - wider adoption of End-to-End approaches like the embedded emissions of a product's parts } \\
\text { throughout its life cycle during the bill of materials phase (Song \& Lee, 2010) }\end{array}$ \\
\hline & $\begin{array}{l}\text { - coordination, alignment, collaboration and information issue having to be revisited (efficient } \\
\text { carbon management will be an additional driver and responsibilities, regarding GHG emissions, } \\
\text { among partners will have to be redefined) } \\
\text { - aspects of centralized versus decentralized supply chain networks to be reconsidered } \\
\text { - agile supply chains forced to find alternative ways of fulfilling emergency orders in terms of } \\
\text { reduced carbon emissions } \\
\text { - Just-in-Time systems having to be revisited as their need for frequent deliveries contradicts } \\
\text { carbon emissions reductions targets } \\
\text { - vulnerabilities of leagile supply chains needing further examination (positioning of the decoupling } \\
\text { point) }\end{array}$ \\
\hline
\end{tabular}
Table 2. Climate change implications for supply chain design

Climate change implications

need for efficient carbon management by partners across the entire supply chain (Carbon

new or different criteria for the selection of sourcing agents (low carbon constraints, effective (

changes of buyers' negotiating power over suppliers (cost, quality and lead time should be

Project, 2011b)

- proximity to suppliers and "near sourcing" becoming key-sourcing drivers (Capgemini, 2011)

considerations regarding natural resources and their availability, quality and price 2008)

incorporation of carbon considerations into contract management

emissions reduction forcing total miles driven and number of nodes downwards

higher consolidation of nodes and more consolidated and aggregated shipments (Global technology, the utilization of low carbon fuels, the usage of lightweight materials, aerodynamics, optimization (The Climate Group, 2008) and capacity planning etc

switches between the usage of energy and less energy intensive transportation modes (Winebrake et al., 2008)

products (collaborative transportation management) (Global Commerce Initiative \& Capgemini, 2008)

transportation assets placed in locations where vulnerability assessments have been carried out

evaluation of alternative scenarios for product design using GHG inventories involving alternative materials, sources of purchasing, production processes, parameters affecting better handling and

wider adoption of End-to-End approaches like the embedded emissions of a product's parts among partners will have to be redefined) reduced carbon emissions

carbon emissions reductions targets

vulnerabilities of leagile supply chains needing further examination (positioning of the decoupling 


\subsection{Implications of climate change for supply chain operations management}

As shown in Figure 2, climate change stresses will affect supply chains also at the operations management level. Physical hazards like extreme weather patterns will ultimately affect routing and scheduling programs, inventory planning and control, material requirements planning, production scheduling, etc. As a consequence, mid-term planning regarding the aforementioned schedules and programs may require more frequent revisions as a result of particular climate change impacts. Generally, at the operational level, supply chains might be faced with increased disruption risks attributed to climate change and increased insurance costs.

Climate change poses significant risks to supply chain continuity. Many recent events have particularly demonstrated how vulnerable supply chain operations are to extreme weather patterns. For example, the recent flooding in Thailand has caused a tremendous shortfall for hard disks, affecting finished products and prices across several industrial sectors. Disruptions threaten the continuity of products' flow across the various agents within supply chain networks. Lack of inventory, carrier delays, transport congestion, and volatility of costs are among the basic impacts of disruptions (Gurning, Cahoon, Nguyen \& Achmadi, 2011).

Apart from disruptions, supply chains are likely to experience higher insurance costs attributed to climate change hazards. The financial impact of extreme weather events caused by climate change may be eased by the insurance industry, with claims related to natural catastrophes rising enormously during the last few years (Mills, 2009). All the assets across a supply chain as well as shipments of raw materials and finished products are vulnerable to extreme weather patterns. As a consequence, extended insurance practices should be adopted by firms in order to protect all the assets and movements across the supply chain. Climate change might also affect the so-called liability insurance risks. Insurers are faced with such risks from claims of third-parties who allege injury or property damage that may be the fault of the insured (Ross, Mills \& Hecht, 2007). Extreme weather events along with the fact that big corporations are progressively adopting global sourcing practices will result to higher liability risks. Such risks present a new field of controversy among supply chain partners where responsibilities of each partner will also have to be redefined. Liability risks might also trigger slight changes to supply chain contracts and third-party logistics providers are likely to be affected as well.

\section{Coping with a changing climate: the road ahead}

Even if business manages to reduce its carbon emissions in the near future, it will still experience in the long term serious impacts attributed to climate change. Therefore, businesses should draft adaptation policies towards ameliorating the negative effects of climate change while seizing new opportunities. Several decision making frameworks for adaptation to climate change have already been developed (Australian Greenhouse Office, 2005; Willows \& Connell, 2003) intended for local governments and business support. These could be used as 
an initial basis for the development of robust adaptation frameworks in the case of supply chain networks as well. Generally, future research attempts regarding supply chain adaptation to climate change should give priority to the development of decision making frameworks based on both impact and vulnerability assessments and the study of relevant issues. Such assessments could identify several aspects of climate change risks like the nature of disruptions attributed to climate change and the climate change vulnerability at several tiers across the entire supply chain. The interested reader is referred to (Füssel \& Klein, 2006) for further information regarding the concepts of climate change vulnerability, adaptation etc. A roadmap of future research approaches regarding climate change and SCM is presented in Table 3.

Developing robust adaptation frameworks for supply chains will also necessitate a better understanding of several issues like logistics managers' perception and awareness for climate change, the set of organizational, structural, institutional and financial barriers impeding the implementation of adaptation practises, any challenges of actually implementing adaptation practices and relevant costs, and the scalability of the adaptation approach. Other interesting fields for research could be the study of coordination aspects of supply chains in view of climate change and especially the relationships between suppliers and buyers and how carbon management affects aspects of coordination and alignment among them. Finally, more robust trade-off frameworks should be developed where certain performance metrics (cost, lead time, quality, service level and carbon) would be weighted out in such a way that a certain level of efficiency and responsiveness is maintained across the entire supply chain.

\begin{tabular}{|c|c|c|c|}
\hline $\begin{array}{c}\text { SCM } \\
\text { attributes }\end{array}$ & Logistical determinants & Methodological frameworks & Objectives \\
\hline \multirow{3}{*}{$\begin{array}{l}\text { Supply chain } \\
\text { configuration }\end{array}$} & $\begin{array}{l}\text { - defining exposure of } \\
\text { infrastructure and assets } \\
\text { to climate-related stimuli } \\
\text { - contingency plans for } \\
\text { managing disruptions }\end{array}$ & $\begin{array}{l}\text { multidisciplinary } \\
\text { approaches } \\
\text { (mathematical } \\
\text { programming bound with } \\
\text { Life Cycle Analysis or } \\
\text { Risk Management } \\
\text { approaches) }\end{array}$ & $\begin{array}{l}\text { - development of tailor-made } \\
\text { adaptation frameworks } \\
\text { - enhancement of adaptive capacity } \\
\text { - defining causal linkages in the } \\
\text { supply chain leading to } \\
\text { maladaptation } \\
\text { - safeguarding continuity }\end{array}$ \\
\hline & $\begin{array}{l}\text { - de-localisation of } \\
\text { production } \\
\text { - trade-off approaches } \\
\text { - consolidation of nodes due } \\
\text { to policy regulation }\end{array}$ & $\begin{array}{l}\text { - prescriptive approaches } \\
\text { (optimization) } \\
\text { - descriptive approaches } \\
\text { (simulation) } \\
\text { - exploratory } \\
\text { researches/case studies }\end{array}$ & $\begin{array}{l}\text { accrued benefits from } \\
\text { diversification of globalized } \\
\text { networks }\end{array}$ \\
\hline & $\begin{array}{l}\text { - decoupling } \\
\text { point/postponement } \\
\text { strategies } \\
\text { - product perspectives }\end{array}$ & $\begin{array}{l}\text { - exploratory } \\
\text { researches/case studies }\end{array}$ & $\begin{array}{l}\text { - efficiency and responsiveness } \\
\text { maintained across the supply chain } \\
\text { - reconfiguration of supply chain } \\
\text { networks } \\
\text { - achieving robustness and } \\
\text { resilience }\end{array}$ \\
\hline
\end{tabular}




\begin{tabular}{|c|c|c|c|}
\hline $\begin{array}{l}\text { SCM } \\
\text { attributes }\end{array}$ & Logistical determinants & Methodological frameworks & Objectives \\
\hline \multirow{2}{*}{$\begin{array}{l}\text { Cross- } \\
\text { functional } \\
\text { drivers } \\
\text { (sourcing, } \\
\text { information } \\
\text { etc) }\end{array}$} & $\begin{array}{l}\text { - aspects of suppliers' } \\
\text { engagement } \\
\text { - establishment of } \\
\text { incentives among supply } \\
\text { chain partners for } \\
\text { efficiently managing } \\
\text { carbon } \\
\text { - climate change-related } \\
\text { aspects embodied within } \\
\text { contracts } \\
\text { - liability insurance risks }\end{array}$ & $\begin{array}{l}\text { - game theory } \\
\text { - cost-benefit analysis } \\
\text { - comparative analysis } \\
\text { - surveys/interviews } \\
\text { - exploratory } \\
\text { researches/case studies }\end{array}$ & $\begin{array}{l}\text { - tracing of enablers and inhibitors } \\
\text { for efficient carbon management } \\
\text { - drafting win-win sourcing agendas } \\
\text { - possible shift of costs } \\
\text { - capturing volatility of markets } \\
\text { - market and economic } \\
\text { diversification }\end{array}$ \\
\hline & $\begin{array}{l}\text { - sharing of information } \\
\text { (carbon accounting } \\
\text { systems) } \\
\text { - Information Technology } \\
\text { and its role towards } \\
\text { managing carbon or } \\
\text { ameliorating the impacts } \\
\text { of climate change hazards }\end{array}$ & $\begin{array}{l}\text { - } \text { surveys/interviews } \\
\text { - exploratory } \\
\text { researches/case studies } \\
\text { - conceptual theory }\end{array}$ & $\begin{array}{l}\text { understanding impediments to } \\
\text { adapting to climate change } \\
\text { - efficient emissions auditing } \\
\text { - using climate change stimuli for } \\
\text { leveraging global supply chains } \\
\text { - theoretical foundation of SCM } \\
\text { practices }\end{array}$ \\
\hline \multirow[t]{3}{*}{$\begin{array}{l}\text { Alignment, } \\
\text { coordination, } \\
\text { integration } \\
\text { and control } \\
\text { mechanisms }\end{array}$} & $\begin{array}{l}\text { - internal and external } \\
\text { functional co-ordination } \\
\text { collaborative innovation } \\
\text { and alignment (when } \\
\text { drafting climate change } \\
\text { agendas) }\end{array}$ & $\begin{array}{l}\text { - empirical research } \\
\text { - case studies } \\
\text { - exploratory researches } \\
\text { - conceptual theory }\end{array}$ & $\begin{array}{l}\text { - clarification of overarching } \\
\text { responsibilities } \\
\text { - defining and prohibiting causal } \\
\text { linkages in the supply chain } \\
\text { leading to possible misalignment } \\
\text { - assessing coordination and } \\
\text { integration discrepancies } \\
\text { stemming from climate change } \\
\text { drivers } \\
\text { upgrading cooperation to } \\
\text { engagement }\end{array}$ \\
\hline & - supply chain integration & $\begin{array}{l}\text { - } \text { benchmarking/best } \\
\text { practices } \\
\text { - comparative assessments } \\
\text { - conceptual theory } \\
\text { - case studies }\end{array}$ & $\begin{array}{l}\text { - best adaptation practices (reactive } \\
\text { or proactive) } \\
\text { cross-boundary synergy effects } \\
\text { and value creation/sharing } \\
\text { (vertical and horizontal) }\end{array}$ \\
\hline & - performance & $\begin{array}{l}\text { - conceptual theory } \\
\text { - case studies }\end{array}$ & - long-term economic performance \\
\hline
\end{tabular}

Table 3. Suggested areas for future research

\section{Concluding remarks}

Serious physical and, consequently, economic and market risks threaten the business world as a result of climate change. Such threats vary across different sectors, although some opportunities may also appear. Extreme natural events and other phenomena related to global warming may damage industrial plants and commercial premises, disrupt operations, dislocate 
plants and customers, reduce purchasing power and decrease consumer demand, deplete agriculture resources etc. Climate change mitigation and adaptation policies have also come into force. Such policies as, for example, in the case of emissions reduction, while aiming at reducing and finally eliminating climate change risks, may adversely affect business operations. Therefore, businesses have to strive, apart from their pure economic objectives, for compliance with environmental restrictions and international accords, for investments in new technologies less harmful for the environment or yielding lower carbon emissions and for meeting demands of customers' market for more environmental friendly products and services.

In this paper an attempt to explore the interrelationships between climate change and supply chain operations, particularly the impacts of the former to the latter, has been made. Potential impacts of climate change upon specific operations along the supply chain were identified and implications of climate change drivers for supply chain strategic and operational decision making were explored. The conceptual background presented in this paper may serve as an initial basis for future research attempts challenging academics and researchers to further explore the interrelationships between climate change and SCM.

\section{References}

Abdallah, T., Farhat, A., Diabat, A., \& Kennedy, S. (2011). Green supply chains with carbon trading and environmental sourcing: Formulation and life cycle assessment. Applied Mathematical Modelling, 36(9), 4271-4285. http://dx.doi.org/10.1016/j.apm.2011.11.056

Alves Jr, G., MacIel, P., Lim, R., Magnani, F., \& Arcoverde Jr, A. (2011). Towards the evaluation of environment and business trade-offs in supply chains. Electronic Notes in Theoretical Computer Science, 275(1), 5-21. http://dx.doi.org/10.1016/j.entcs.2011.09.002

Australian Greenhouse Office. (2005). Climate Change Risk and Vulnerability: Promoting an efficient adaptation response in Australia. Retrieved October 10, 2012 from http://www.sfrpc.com/Climate\%20Change/4.pdf

Ben Naylor, J., Naim, M., \& Berry, D. (1999). Leagility: integrating the lean and agile manufacturing paradigms in the total supply chain. International Journal of Production Economics, 62(1-2), 107-118. http://dx.doi.org/10.1016/S0925-5273(98)00223-0

Benjaafar, S., Li, Y., \& Daskin, M. (2013). Carbon footprint and the management of supply chains: Insights from simple models. IEEE Transactions on Automation Science and Engineering, 10(1), 99-116. http://dx.doi.org/10.1109/TASE.2012.2203304

Bevilacqua, M., Ciarapica, F.E., Giacchetta, G., \& Marchetti, B. (2011). A carbon footprint analysis in the textile supply chain. International Journal of Sustainable Engineering, 4(1), 24-36. http://dx.doi.org/10.1080/19397038.2010.502582 
Capgemini. (2011). 2012 Third-party Logistics study. The State of Logistics Outsourcing. Retrieved October 10, 2012 from http://www.3plstudy.com/downloads/2012-3pl-study/

Carbon Disclosure Project. (2011a). CDP Global 500 Report 2011. Accelerating Low Carbon Growth. Retrieved October 02, 2012 from https://www.cdproject.net/enus/results/pages/cdp-global-500-report-2011.aspx

Carbon Disclosure Project. (2011b). Supply Chain Report 2011. Migrating to a low carbon economy through leadership and collaboration. Retrieved October 4, 2012 from https://www.cdproject.net/CDPResults/CDP-2011-Supply-Chain-Report.pdf

Chaabane, A., Ramudhin, A., Kharoune, M., \& Paquet, M. (2011). Trade-off model for carbon market sensitive green supply chain network design. International Journal of Operational Research, 10(4), 416-441. http://dx.doi.org/10.1504/IJOR.2011.039711

Chaabane, A., Ramudhin, A., \& Paquet, M. (2010). Design of sustainable supply chains under the emission trading scheme. International Journal of Production Economics, 135(1), 37-49. http://dx.doi.org/10.1016/j.ijpe.2010.10.025

Christopher, M. (1998). Logistics and Supply Chain Management: Strategies for Reducing Cost and Improving Service. Second ed. London: Financial Times/Pitman Publishing.

Christopher, M. (2000). The agile supply chain - Competing in volatile markets. Industrial marketing management, 29(1), 37-44. http://dx.doi.org/10.1016/S0019-8501(99)00110-8

Dekker, R., Bloemhof, J., \& Mallidis, I. (2012). Operations Research for green logistics - An overview of aspects, issues, contributions and challenges. European Journal of Operational Research, 219(3), 671-679. http://dx.doi.org/10.1016/j.ejor.2011.11.010

Edwards, J., McKinnon, A., \& Cullinane, S. (2011). Comparative carbon auditing of conventional and online retail supply chains: A review of methodological issues. Supply Chain Management, 16(1), 57-63. http://dx.doi.org/10.1108/13598541111103502

Elhedhli, S., \& Merrick, R. (2012). Green supply chain network design to reduce carbon emissions. Transportation Research Part D: Transport and Environment, 17(5), 370-379. http://dx.doi.org/10.1016/j.trd.2012.02.002

EPA Climate Leaders. (2010). Managing Supply Chain Greenhouse Gas Emissions. Lessons Learned for the road ahead. Retrieved October 7, 2012 from http://www.epa.gov/climateleaders/documents/resources/managing-supplychain-emis2010.pdf

Füssel, H.M., \& Klein, R.J.T. (2006). Climate change vulnerability assessments: An evolution of conceptual thinking. Climatic Change, 75(3), 301-329. http://dx.doi.org/10.1007/s10584-006-03293 
Fei, H., \& Houyuan, Y. (2010). Analysis on Low Carbon Strategy of Third Party Logistics. Paper presented at the 7th International Conference on Innovation \& Management, China.

Ford. (2005). Ford report on the business impact of climate change. Retrieved November 08, 2012 from http://media.ford.com/downloads/05_climate.pdf

Gay, C., Estrada, F., Conde, C., Eakin, H., \& Villers, L. (2006). Potential impacts of climate change on agriculture: A case of study of coffee production in Veracruz, Mexico. Climatic Change, 79(3-4), 259-288. http://dx.doi.org/10.1007/s10584-006-9066-x

Global Commerce Initiative \& Capgemini. (2008). 2016 Future Supply Chain. Serving Consumers in a Sustainable Way. Retrieved November 22, 2012 from http://www.futuresupplychain.com/downloads/

Gurning, R.O.S., Cahoon, S., Nguyen, H.O., \& Achmadi, T. (2011). Mitigating maritime disruptions: Evidence from the Australian-Indonesian wheat supply chain. International Journal of Shipping and Transport Logistics, 3(4), 406-429. http://dx.doi.org/10.1504/IJSTL.2011.041135

Halldórsson, A., \& Kovács, G. (2010). The sustainable agenda and energy efficiency: Logistics solutions and supply chains in times of climate change. International Journal of Physical Distribution and Logistics Management, 40(1-2), 5-13. http://dx.doi.org/10.1108/09600031011018019

Harris, I., Naim, M., Palmer, A., Potter, A., \& Mumford, C. (2011). Assessing the impact of cost optimization based on infrastructure modelling on $\mathrm{CO} 2$ emissions. International Journal of Production Economics, 131(1), 313-321. http://dx.doi.org/10.1016/j.ijpe.2010.03.005

Hasan, A.H.R. (2010). Measuring Climate Change Risk on Supply Chain of Rice in Bangladesh. In Sumi, A., Fukushi, K., Honda, R. \& Hassan, K.M. (Eds.). Sustainability in Food and Water, 18, 327-334. Springer Netherlands. http://dx.doi.org/10.1007/978-90-481-9914-3_32

Haverkort, A.J., \& Verhagen, A. (2008). Climate change and its repercussions for the potato supply chain. Potato Research, 51(3-4), 223-237. http://dx.doi.org/10.1007/s11540-008-9107-0

Hitchcock, T. (2012). Low carbon and green supply chains: The legal drivers and commercial pressures. Supply Chain Management, 17(1), 98-101. http://dx.doi.org/10.1108/13598541211212249

Hoen, K.M.R., Tan, T., Fransoo, J.C., \& van Houtum, G.J. (2012). Effect of carbon emission regulations on transport mode selection under stochastic demand. Flexible Services and Manufacturing Journal, 1-26. 
Hoffman, A., \& Woody, J. (2008). Climate change: what's your business strategy? Harvard Business Press.

Hsu, C.W., Kuo, T.C., Chen, S.H., \& Hu, A.H. (2011). Using DEMATEL to develop a carbon management model of supplier selection in green supply chain management. Journal of Cleaner Production.

Hua, G., Cheng, T.C.E., \& Wang, S. (2011). Managing carbon footprints in inventory management. International Journal of Production Economics, 132(2), 178-185. http://dx.doi.org/10.1016/j.ijpe.2011.03.024

Humphrey, N. (2008). Potential impacts of climate change on U.S. Transportation. TR NewS 256, 21-24.

Jacxsens, L., Luning, P.A., van der Vorst, J.G.A.J., Devlieghere, F., Leemans, R., \& Uyttendaele, M. (2010). Simulation modelling and risk assessment as tools to identify the impact of climate change on microbiological food safety - The case study of fresh produce supply chain. Food Research International, 43(7), 1925-1935. http://dx.doi.org/10.1016/j.foodres.2009.07.009

Jaegler, A., \& Burlat, P. (2012). Carbon friendly supply chains: A simulation study of different scenarios. Production Planning and Control, 23(4), 269-278. http://dx.doi.org/10.1080/09537287.2011.627656

Jira, C.F., \& Toffel, M.W. (2011). Engaging Supply Chains in Climate Change. Working paper 12-026, Harvard Business School.

Jones, G.V., White, M.A., Cooper, O.R., \& Storchmann, K. (2005). Climate change and global wine quality. Climatic Change, 73(3), 319-343. http://dx.doi.org/10.1007/s10584-005-4704-2

Kim, N.S., Janic, M., \& Van Wee, B. (2009). Trade-off between carbon dioxide emissions and logistics costs based on multiobjective optimization. Transportation Research Record: Journal of the Transportation Research Board, 2139, 107-116. http://dx.doi.org/10.3141/2139-13

King, A., \& Lenox, M. (2001). Lean and green? An empirical examination of the relationship between lean production and environmental performance. Production and Operations Management, 10(3), 244-256. http://dx.doi.org/10.1111/j.1937-5956.2001.tb00373.x

Kolk, A., \& Pinkse, J. (2005). Business responses to climate change: Identifying emergent strategies. California Management Review, 47(3). http://dx.doi.org/10.2307/41166304

Kolk, A., \& Pinkse, J. (2007). Towards strategic stakeholder management? Integrating perspectives on sustainability challenges such as corporate responses to climate change. Corporate Governance, 7(4), 370-378. http://dx.doi.org/10.1108/14720700710820452 
Laderach, P., Lundy, M., Jarvis, A., Ramirez, J., Portilla, E.P., Schepp, K., et al. (2011). Predicted Impact of Climate Change on Coffee Supply Chains In W. Leal Filho (Ed.), The Economic, Social and Political Elements of Climate Change, pp. 703-723. Springer Berlin Heidelberg. http://dx.doi.org/10.1007/978-3-642-14776-0_42

Lee, K.H. (2011). Integrating carbon footprint into supply chain management: The case of Hyundai Motor Company (HMC) in the automobile industry. Journal of Cleaner Production, 19(11), 1216-1223. http://dx.doi.org/10.1016/j.jclepro.2011.03.010

Lee, K.H. (2012). Carbon accounting for supply chain management in the automobile industry. Journal of Cleaner Production, 36, 83-93. http://dx.doi.org/10.1016/j.jclepro.2012.02.023

Letmathe, P., \& Balakrishnan, N. (2005). Environmental considerations on the optimal product mix. European Journal of Operational Research, 167(2), 398-412. http://dx.doi.org/10.1016/j.ejor.2004.04.025

Maoh, H., Kanaroglou, P., \& Woudsma, C. (2008). Simulation model for assessing the impact of climate change on transportation and the economy in Canada. Transportation Research Record: Journal of the Transportation Research Board, 2067, 84-92. http://dx.doi.org/10.3141/2067-10

Mason-Jones, R., Naylor, B., \& Towill, D. (2000). Lean, agile or leagile? Matching your supply chain to the marketplace. International Journal of Production Research, 38(17), 4061-4070. http://dx.doi.org/10.1080/00207540050204920

McKinnon, A. (2009). The present and future land requirements of logistical activities. Land Use Policy, 26(Suppl. 1), S293-S301. http://dx.doi.org/10.1016/j.landusepol.2009.08.014

McKinnon, A. (2010). Product-level carbon auditing of supply chains: Environmental imperative or wasteful distraction? International Journal of Physical Distribution and Logistics Management, 40(1-2), 42-60. http://dx.doi.org/10.1108/09600031011018037

Mills, E. (2009). A global review of insurance industry responses to climate change. Geneva Papers on Risk and Insurance: Issues and Practice, 34(3), 323-359. http://dx.doi.org/10.1057/gpp.2009.14

Nash, A., Weidmann, U., \& Luethi, M. (2009). Can information technology help rail play a greater role in preventing climate change? Transportation Research Record: Journal of the Transportation Research Board, 2139, 133-141. http://dx.doi.org/10.3141/2139-16

Pan, S., Ballot, E., \& Fontane, F. (2010). The reduction of greenhouse gas emissions from freight transport by pooling supply chains. 
Peltola, H., Ikonen, V.P., Gregow, H., Strandman, H., Kilpeläinen, A., Venäläinen, A., et al. (2010). Impacts of climate change on timber production and regional risks of wind-induced damage to forests in Finland. Forest Ecology and Management, 260(5), 833-845. http://dx.doi.org/10.1016/j.foreco.2010.06.001

Piecyk, M.I., \& McKinnon, A.C. (2010). Forecasting the carbon footprint of road freight transport in 2020. International Journal of Production Economics, 128(1), 31-42. http://dx.doi.org/10.1016/j.ijpe.2009.08.027

PricewaterhouseCoopers. (2008). Global Sourcing: Shifting Strategies. A survey of retail and consumer companies. Retrieved November 10, 2012 from http://www.pwc.com/at/en/publikationen/branchen-und-wirtschaftsstudien/global-sourcingshifting-strategies.pdf

Product Policy Institute. (2009). Products, Packaging and US Greenhouse Gas Emissions. $\begin{array}{llll}\text { Retrieved November } & 0812 \text { from }\end{array}$ http://www.productpolicy.org/ppi/attachments/PPI_Climate Change and Products White Pa per_September_2009.pdf

Ramudhin, A., Chaabane, A., \& Paquet, M. (2010). Carbon market sensitive sustainable supply chain network design. International Journal of Management Science and Engineering Management, 5(1), 30-38.

Reich-Weiser, C., \& Dornfeld, D.A. (2009). A discussion of greenhouse gas emission tradeoffs and water scarcity within the supply chain. Journal of Manufacturing Systems, 28(1), 23-27. http://dx.doi.org/10.1016/j.jmsy.2009.04.002

Rizet, C., Browne, M., Cornelis, E., \& Leonardi, J. (2012). Assessing carbon footprint and energy efficiency in competing supply chains: Review - Case studies and benchmarking. Transportation Research Part D: Transport and Environment, 17(4), 293-300. http://dx.doi.org/10.1016/j.trd.2012.01.002

Ross, C., Mills, E., \& Hecht, S.B. (2007). Limiting liability in the greenhouse: insurance riskmanagement strategies in the context of global climate change. Stanford Journal of International Law, 43A(1), 251-317.

Rothenberg, S., Pil, F.K., \& Maxwell, J. (2001). Lean, green, and the quest for superior environmental performance. Production and Operations Management, 10(3), 228-243. http://dx.doi.org/10.1111/j.1937-5956.2001.tb00372.x

Sadegheih, A., Drake, P.R., Li, D., \& Sribenjachot, S. (2011). Global supply chain management under the carbon emission trading program using mixed integer programming and genetic algorithm. International Journal of Engineering, Transactions B: Applications, 24(1), 37-53. 
Shaw, K., Shankar, R., Yadav, S.S., \& Thakur, L.S. (2012). Supplier selection using fuzzy AHP and fuzzy multi-objective linear programming for developing low carbon supply chain. Expert Systems with Applications, 39(9), 8182-8192. http://dx.doi.org/10.1016/j.eswa.2012.01.149

Song, J.S., \& Lee, K.M. (2010). Development of a low-carbon product design system based on embedded GHG emissions. Resources, Conservation and Recycling, 54(9), 547-556. http://dx.doi.org/10.1016/j.resconrec.2009.10.012

Stern Review. (2006). Stern Review on the Economics of Climate Change. HM Treasury, Cabinet Office. Retrieved December 3, 2012 from http://webarchive.nationalarchives.gov.uk/ $\pm /$ http://www.hm-treasury.gov.uk/stern review report.htm

Sundarakani, B., De Souza, R., Goh, M., Wagner, S.M., \& Manikandan, S. (2010). Modeling carbon footprints across the supply chain. International Journal of Production Economics, 128(1), 43-50. http://dx.doi.org/10.1016/j.ijpe.2010.01.018

Sussman, F., \& Freed, J. (2008). Adapting to climate change: A business approach. Pew Center on Global Climate Change. Retrieved October 12, 2012 from http://www.pewclimate.org/docUploads/Business-Adaptation.pdf

The Climate Group. (2008). SMART 2020: Enabling the low carbon economy in the information age. $\quad$ Retrieved October 24, 2012 from http://www.smart2020.org/ assets/files/02 Smart2020Report.pdf

Tirado, M.C., Clarke, R., Jaykus, L.A., McQuatters-Gollop, A., \& Frank, J.M. (2010). Climate change and food safety: A review. Food Research International, 43(7), 1745-1765. http://dx.doi.org/10.1016/j.foodres.2010.07.003

Turner, D.A., Kemp, S., \& Williams, I. (2011). Carbon footprinting in the UK waste management sector. Carbon Management, 2(6), 677-690. http://dx.doi.org/10.4155/cmt.11.67

White, A. (2007). A New Wave of SCM Innovation Must Address Climate Change Concerns. Gartner. ID Number: G00149710. Retrieved October 10, 2012 from http://www.lexian.com.au/upload/Gartner\%20New\%20Wave\%20of\%20SCM \%20Innovation.pdf

Willows, R., \& Connell, R. (2003). Climate adaptation: Risk, uncertainty and decision-making. Retrieved October 10, 2012 from http://www.ukcip.org.uk/wordpress/wpcontent/PDFs/Risk.pdf

Winebrake, J.J., Corbett, J.J., Falzarano, A., Hawker, J.S., Korfmacher, K., Ketha, S., et al. (2008). Assessing energy, environmental, and economic tradeoffs in intermodal freight transportation. Journal of the Air and Waste Management Association, 58(8), 1004-1013. http://dx.doi.org/10.3155/1047-3289.58.8.1004 
World Resources Institute \& World Business Council for Sustainable Development. (2011). Product Life Cycle Accounting and Reporting Standard. Retrieved November 02, 2012 from http://www.ghgprotocol.org/files/ghgp/Product\%20Life\%20Cycle\%20Accounting\%20and \%20Reporting\%20Standard.pdf

Yang, H., \& Zhang, J. (2011). The strategies of advancing the cooperation satisfaction among enterprises based on low carbon supply chain management. Paper presented at the 2010 International Conference on Energy, Environment and Development, Kuala Lumpur.

Journal of Industrial Engineering and Management, 2013 (www.jiem.org)

Article's contents are provided on a Attribution-Non Commercial 3.0 Creative commons license. Readers are allowed to copy, distribute and communicate article's contents, provided the author's and Journal of Industrial Engineering and Management's names are included. It must not be used for commercial purposes. To see the complete license contents, please visit http://creativecommons.org/licenses/by-nc/3.0/.
} 